\title{
Sprawozdanie z seminarium naukowego „Narracje andragogiczne od pokolenia "boomu edukacyjnego« do pokolenia Y i Z" - Warszawa, 12 grudnia 2013 r.
}

Katedra Edukacji Ustawicznej i Andragogiki Wydziału Pedagogicznego Uniwersytetu Warszawskiego zorganizowała seminarium naukowe poświęcone biografiom zawodowym absolwentów specjalizacji andragogicznej. Seminarium naukowe wpisało się w obchody 60-lecia Wydziału Pedagogicznego.

Oficjalnego otwarcia seminarium i przywitania gości dokonała kierownik Katedry Edukacji Ustawicznej i Andragogiki dr hab. Ewa Skibińska. Następnie swoje wystąpienia miała Prodziekan ds. naukowych Wydziału Pedagogicznego Uniwersytetu Warszawskiego dr hab. Anna Zielińska, prof. UW. Opowiedziała o obchodach 60-lecia Wydziału Pedagogicznego. Zwróciła uwagę na rolę zmian generacyjnych w naszym kraju. Podkreśliła, że kondycja społeczeństwa zależy od młodego pokolenia i tym bardziej niezwykle istotne jest poświęcanie tej problematyce wnikliwej uwagi. Podsumowując zwróciła uwagę, że seminarium naukowe kończy obchody 60-lecia tak ważnymi zagadnieniami, jakimi są rozważania dotyczące młodych ludzi.

Pierwszą sesję naukową poprowadziła dr Ewa Dębska z Uniwersytetu Warszawskiego. Sesję otworzyło wystąpienie zatytułowane: Niepokój o kształcenie ustawiczne, które wygłosił prof. dr hab. Józef Półturzycki z Uniwersytetu Warszawskiego. Odnosząc się do dokumentów międzynarodowych poświęconych edukacji ustawicznej, zwrócił uwagę na wciąż istniejący problem braku definicji edukacji ustawicznej w Polsce. Podkreślił, że istota edukacji ustawicznej to reforma systemu kształcenia i przywrócenie odrzuconych wartości i ideałów mających swoje źródło w edukacji. Konkludu- 
jąc prelegent zachęcił uczestników do szukania nowej realizacji idei edukacji ustawicznej.

W dalszej części sesji referaty wygłosili goście z Czech. Doc. dr. Jaroslav Veteška, Ph.D. z Uniwersytetu Jana Amosa Komeńskiego w Pradze przedstawił referat na temat Rozwój czesko-słowackiej edukacji dorostych od roku 1990. Autor omówił perspektywy rozwoju czesko-słowackiej andragogiki od czasów, gdy przyjmowano kilkuset studentów poprzez start Procesu Bolońskiego, przyjęcie Narodowego Programu Rozwoju obejmującego wszystkie etapy kształcenia od edukacji przedszkolnej aż po kształcenie dorosłych, do ostatniej fazy egalitaryzmu i umasowienia uniwersytetu. Profesor zwrócił uwagę na silne strony andragogiki takie jak: zmiany instytucjonalne oraz rozwój szkół wyższych, a następnie na bariery i słabe strony takie jak: niedostateczną działalność naukową (publikowanie), problemy kadrowe katedry oraz konieczność dopasowania idei life long learning do instytucjonalnych dokumentów.

Kolejne wystąpienie zatytułowane Instytucjonalne podstawy andragogiki - Czeska Społeczność Andragogiczna i inne organizacje edukacji dorosłych wygłosiła dr Jarmila Salivarová z Uniwersytetu Jana Amosa Komeńskiego w Pradze. Prelegentka omówiła działalność oraz znaczenie instytucji zajmujących się w Czechach edukacją dorosłych. Zwróciła uwagę na niezwykle istotną rolę działalności Asociace institucí vzdělávání dospělých ČR (The Association of Adult Education Institutions in the Czech Republic), założonego w 1990 roku i będącego współcześnie największym profesjonalnym stowarzyszeniem edukacji dorosłych w Czeskiej Republice, które specjalizuje się w obszarze edukacji dorosłych. Jak podkreśliła prelegentka, celem Stowarzyszenia jest promowanie interesów i potrzeb instytucji kształcenia dorosłych, współpraca z organami państwa oraz z innymi podmiotami krajowymi i międzynarodowymi, a także wymiana doświadczeń i tworzenie partnerstwa. Stowarzyszenie organizuje liczne szkolenia, takie jak Certified Trainer dla Edukacji Dorostych, Certified Manager dla Edukacji Dorostych. Zwróciła także uwagę, że Stowarzyszenie od 1995 roku organizuje tzw. tygodnie edukacji dorosłych oraz międzynarodowe wizyty studyjne, seminaria, konferencje i warsztaty. Bierze także udział w badaniach naukowych krajowych i międzynarodowych. Jest także współwydawcą czasopisma Andragogika, poświęconego naukowym rozważaniom dotyczącym teorii i praktyki rozwoju i edukacji dorosłych.

Pierwszą sesję zakończyło wystąpienie dr. Jiří Pavlů, Ph.D. z Uniwersytetu Ostrawskiego zatytułowane Kogo uczymy? - andragogiczna sonda wśród studentów. Prelegent opowiadał o wynikach badania, które przeprowadził 
wśród studentów studiów niestacjonarnych, które dotyczyło ilości czasu jaki poświęcają oni autoedukacji. Jedną grupę badanych stanowili studenci kształcący się na koszt państwa (ok. 50\% ogółu wszystkich badanych), a drugą osoby płacące samodzielnie za swoją edukację na studiach wyższych (ok. 20\% ogółu wszystkich badanych). Głównym wynikiem badań było zróżnicowanie stosunku do edukacji poszczególnych grup studentów. Studenci płacący samodzielnie za swoją edukację wykazali postawę roszczeniową konieczność zapłaty jest dla nich jednoznaczna $\mathrm{z}$ otrzymaniem towaru czyli edukacji. Jednocześnie najpoważniejszymi barierami dla płacących, aby korzystać z form autoedukacji, były ograniczenia czasowe i finansowe.

Po krótkiej przerwie drugą sesję naukową poprowadził dr Krzysztof Pierścieniak z Uniwersytetu Warszawskiego. Pierwsze wystąpienie dr hab. Ewy Skibińskiej z Uniwersytetu Warszawskiego poświęcone zostało tematowi: Narracje $w$ badaniach biografii zawodowych. Autorka we wstępie opowiedziała o istocie i celach badania biografii absolwentów przeprowadzonego przez Katedrę Edukacji Ustawicznej i Andragogiki Uniwersytetu Warszawskiego. Następnie wygłosiła referat natury metodologicznej poświęcony problematyce narracji. Zwróciła uwagę na wzrost popularności pojęcia narracji w naukach społecznych, w tym także w andragogice, po tzw. zwrocie biograficznym oraz zwrocie lingwistycznym mającym miejsce w latach 80. XX wieku. Następnie podkreśliła wieloaspektowość oraz zróżnicowanie i wielość kontekstów, w których funkcjonuje pojęcie narracji. Autorka określiła narrację mianem konstruktu indywidualnego, dynamicznego, zmieniającego się w czasie, łączącego przyszłość, teraźniejszość i wizje przyszłości. W drugiej części wystąpienia prelegentka wyjaśniła znaczenie pojęcia biografii, w tym biografii zawodowej oraz ukazała jej kontekstowość. Podsumowując dr hab. Ewa Skibińska zwróciła uwagę, iż narracja w badaniach biografii zawodowej jest językowym konstruktem tej biografii oraz autobiografią wyrażoną w języku, będącą wytworem komunikacji.

Następnie dr Ewa Dębska z Uniwersytetu Warszawskiego wygłosiła referat zatytułowany: Biografie zawodowe pokolenia X i Y - perspektywa temporalna. Autorka przedstawiła wstępne wyniki pierwszego etapu badań dotyczących biografii zawodowych absolwentów, prowadzonych przez Katedrę Andragogiki i Edukacji Ustawicznej. Autorka zaprezentowała trzy biografie i wyróżniła następujące biografie zawodowe: jednobiegunowq, bipolarnq i zróżnicowanq oraz odpowiadające im orientacje biograficzne: ku przewidywalności zmian, ku poszerzaniu kompetencji oraz ku multiplikacji doświadczenia. Prelegentka wyróżniła również atrybuty wspólne dla biografii zawodowych, takie jak: stosunek do zmiany oraz przekonanie respondentów 
o własnym sprawstwie. Podkreśliła, że absolwenci przypisują sobie samodzielne kierowanie swoją biografią zawodową. Trzecim elementem, na który zwróciła uwagę autorka, było podejście respondentów do wyznaczania planów zawodowych.

Kolejne wystąpienie dr Anny Marianowskiej z Uniwersytetu Warszawskiego dotyczyło rozważań na temat: Edukacja w konstruowaniu biografii pokolenia $X, Y i Z$. W swoim referacie prelegentka przedstawiła uwarunkowania społeczne, polityczne, gospodarcze i technologiczne, które wpłynęły na kształtowanie się młodych ludzi z pokolenia X,Y i Z. Autorka zwróciła szczególną uwagę na temporalne zmiany oczekiwań i podejścia do edukacji absolwentów specjalizacji andragogicznej Wydziału Pedagogicznego Uniwersytetu Warszawskiego oraz wpływu jakie miały na konstruowanie biografii pokolenia X i Y. Autorka poddała także refleksji kwestię oczekiwań i podejścia do edukacji osób należących do pokolenia Z, które za kilka lat staną się uczestnikami edukacji na poziomie wyższym.

Ostatnie wystąpienie dr Krystyny Komosińskiej z Uniwersytetu Warszawskiego pt. Studenci o „Wychowaniu do życia $w$ rodzinie” poświęcone zostało historii powstania oraz istocie tego przedmiotu. Autorka podkreśliła, że propagatorami wdrażania tej edukacji do szkół byli m.in.: Z. Kowalski, T. Łazowski i K. Siwicki, B. Dybowski, B. Popielski, H. Malewska, H. Muszyński, M. Kozakiewicz, M. Trawińska, Z. Lew-Starowicz i K. Szczerba. Zabiegali oni o to, żeby edukacja ta była dostępna na wszystkich etapach kształcenia. Podsumowując wyniki przeprowadzonych przez siebie badań autorka wskazała, że zgodnie z propozycją młodych osób, istotne byłoby zatrudnienie odpowiednio przygotowanych nauczycieli, zmiana treści podstawy programowej z uwzględnieniem standardów europejskich, zmniejszenie liczby tematów proponowanych na ten poziom kształcenia gimnazjalnego z 18 do 8 bloków tematycznych według wskazań europejskich lub zwiększenie liczby godzin na każdą klasę oraz wprowadzenie oceny końcowej za przedmiot, które mogłoby poprawić stosunek uczniów do przedmiotu.

Ostatnim punktem programu była debata poświęcona wygłoszonym wystąpieniom, która została poprowadzona przez dr Krzysztofa Pierścieniaka z Uniwersytetu Warszawskiego. Na początku głos zabrał prof. dr hab. Tadeusz Aleksander z Krakowskiej Akademii im. A. F. Modrzewskiego. Nawiązując do wystąpień zwrócił m.in. uwagę na proces zamiany uczelni w szkoły zawodowe oraz odejście od humanistycznej koncepcji studiów. Następnie prof. dr hab. Józef Półturzycki podkreślił, że obecnie następuje czas demontażu edukacji dorosłych, w którym szkoły dla dorosłych kształcą coraz mniej osób. Uczestnicy nawiązywali także do wystąpień gości z Czech i zadawali 


\section{4 | Sprawozdanie z seminarium naukowego}

szczegółowe pytania dotyczące organizacji tamtejszej edukacji oraz miejsca andragogiki. Podsumowujący głos w dyskusji zabrał dr Tomasz Maliszewski z Akademii Pomorskiej w Słupsku, który wskazał, że istotnym punktem badań absolwentów mogłoby być nawiązanie współpracy ośrodków naukowych.

Podsumowania seminarium dokonała dr hab. Ewa Skibińska, która podziękowała uczestnikom za aktywne uczestnictwo oraz przybycie na konferencję.

Ewa I. Kurek 